\title{
Clinical evaluation of Sephadex gel filtration in estimation of bilirubin binding in serum in neonatal jaundice
}

\author{
J. KAPITULNIK, T. VALAES, N. A. KAUFMANN, and S. H. BLONDHEIM \\ From the Metabolic Laboratory and Departments of Medicine B and Nutrition, Hadassah University Hospital \\ and Hebrew University-Hadassah Medical School, Jerusalem, Israel, and Institute of Child Health, Aghia \\ Sophia Children's Hospital, Athens, Greece
}

Kapitulnik, J., Valaes, T., Kaufmann, N. A., and Blondheim, S. H. (1974). Archives of Disease in Childhood, 49, 886. Clinical evaluation of Sephadex gel filtration in estimation of bilirubin binding in serum in neonatal jaundice. Clinical experience with a Sephadex gel filtration test-kit for the evaluation of bilirubin binding affinity of serum in neonatal jaundice is reported. In serial serum specimens from 166 jaundiced neonates the results of the test in most cases were in accord with the independent clinical decision to perform exchange transfusion. In all 9 cases with clinical kernicterus the Sephadex test was strongly positive (very low bilirubin binding affinity of serum).

The test was positive at lower bilirubin levels and bilirubin/albumin molar ratios in preterm as compared with term neonates, especially in those in poor clinical condition. Among term infants the test indicated an increase in bilirubin binding affinity after the 5 th day of life.

It is generally agreed that the fraction of bilirubin which is not bound to albumin in serum ('unbound' or 'free' bilirubin) is one of the main factors determining the development of bilirubin encephalopathy. The concentration of this bilirubin fraction in serum depends not only on the concentrations of total bilirubin and albumin, but also on the affinity with which the albumin molecule binds bilirubin and on the presence of substances which interfere with the binding of bilirubin.

Evaluation of bilirubin binding in serum by Sephadex gel filtration has been suggested as a means of defining more precisely the need for exchange transfusion in the prevention of kernicterus (Jirsová et al., 1967; Kaufmann, Kapitulnik, and Blondheim, 1969; Zamet and Chunga, 1971; Blondheim et al., 1972; Schiff, Chan, and Stern, 1972). A simple, rapid Sephadex technique has recently been described and used in the evaluation of sera from jaundiced neonates (Blondheim et al., 1972). Since only one preexchange specimen of frozen serum from each infant

Received 17 April 1974. was studied, no firm conclusions as to the clinical value of the test could be drawn.

The present report includes a large number of cases from which serial specimens of fresh serum were studied. The results indicate that the use of this Sephadex gel filtration technique is of definite value in the clinical management of neonatal jaundice.

\section{Clinical material}

Infants who were admitted to the two newborn nurseries of the Aghia Sophia Children's Hospital were studied. Jaundice was the reason for most admissions, but a few infants were admitted because of prematurity and subsequently developed jaundice. The clinical routine included daily examination for signs of kernicterus, such as hypertonicity of the extremities and opisthotonus, absent or incomplete Moro reflex, abnormal grasping and sucking reflexes, abnormal crying, and the 'setting sun' sign.

Clinical management in both nurserv units was similar. Indications for exchange transfusion varied according to the aetiology of the jaundice. In term infants without haemolysis a serum bilirubin concentration of $25 \mathrm{mg} / 100$ $\mathrm{ml}$ was used as an indication for exchange transfusion. 


\section{Sephadex gel filtration in estimation of bilirubin binding in serum in neonatal jaundice}

In cases with haemolytic disease the rate of increase in bilirubin concentration was taken into consideration. In preterm infants, gestational age, birthweight, and the presence of other complications determined the bilirubin level at which exchange transfusion was performed. In more than half of the cases exchange transfusion was already indicated on the basis of these criteria at the time of admission. In 7 term infants exchange transfusion was not performed though the bilirubin levels were between 25 and $30 \mathrm{mg} / 100 \mathrm{ml}$. In 2 of them the bilirubin concentration decreased within a few hours, and in the other 5 the high values occurred after at least one exchange transfusion. Phototherapy with artificial light was not used. In only 3 preterm infants was human serum albumin $(1 \mathrm{~g} / \mathrm{kg})$ used instead of exchange transfusion. Clinical care was completely independent of the results of the Sephadex test, while clinical details were not known to the investigators until after the investigation was completed.

Serum was separated from all blood samples sent routinely to the chemistry laboratory for estimation of bilirubin, was refrigerated at once, and studied 2 to 18 hours later. Blood samples were also taken routinely at the beginning and at the end of exchange transfusion. In a few preterm infants with low serum bilirubin but a positive Sephadex test (see below), the staff was asked to continue sending blood samples even though bilirubin concentrations were decreasing or were below levels thought to be of clinical significance.

\section{Methods}

Total and conjugated (direct-reacting) serum bilirubin were determined routinely in the laboratory using the method of Lathe and Ruthven (1958). However, for the purpose of the present investigation total bilirubin was also determined with a direct-reading bilirubinometer (American Optical Corp., Buffalo, N.Y.). In all cases with levels greater than $25 \mathrm{mg} / 100 \mathrm{ml}$ (the upper limit of accurate measurement of the instrument) and when there was an excess of serum, total bilirubin was also determined by diazotization using the method of Malloy and Evelyn (1937). Versatol Pediatric (Warner-Chilcott Laboratories, Morris Plains, N.J.) was used for standardization. Serum albumin was determined by the acid-ethanol precipitation method of Fernandez, Sobel, and Goldenberg (1966).

The binding of bilirubin to serum albumin was studied using the Kernlute test-kit (Ames-Yissum, Jerusalem, Israel). The test-kit contains columns filled with $2 \mathrm{ml}$ Sephadex G-25, fine (Pharmacia, Uppsala), equilibrated with phosphate buffer $(0.067 \mathrm{~mol} / 1 ., p \mathrm{H} \mathrm{7.45}) . \quad 0.1 \mathrm{ml}$ aliquots of serum were mixed with $0.75 \mathrm{ml}$ phosphate buffer and were run through the column, followed by 2 $\mathrm{ml}$ of buffer to wash the serum out of the column. Serum residues on the walls of the column were removed with cotton swabs. An Ictotest tablet (Ames) was then dissolved in $0.75 \mathrm{ml}$ distilled water and the solution run through the column.

Bilirubin, adsorbed by the Sephadex gel from serum, reacted with the reagent solution to give a blue band which increased in intensity as it passed down the column. The intensity of the band was assessed after all the reagent had entered the Sephadex gel. The staining was graded as follows: negative when there was no blue band, positive $(t)$ when a blue band was present, and strongly positive $(++)$ when a dark blue band appeared against a wide reddish background.

The bilirubin concentration was then artificially increased in sera which gave a negative Sephadex test by adding $0.1 \mathrm{ml}$ aliquots of bilirubin solution to $0.1 \mathrm{ml}$ serum diluted with $0.75 \mathrm{ml}$ buffer. The bilirubin solutions were prepared by dissolving 50 or $100 \mu \mathrm{g}$ preweighed bilirubin, contained in plastic cups, in 1 or 2 $\mathrm{ml}$ of a sodium carbonate solution $(2 \cdot 4 \mathrm{~g} / \mathrm{l}$.). The serum bilirubin concentration was thus effectively increased by $2 \cdot 5,5,7 \cdot 5$, or $10 \mathrm{mg} / 100 \mathrm{ml}$. The Sephadex test was then repeated using these bilirubin-enriched serum mixtures.

In the analysis of the results serum samples were assigned to 'periods' as follows: period I included samples from infants who were not given exchange transfusion and those taken from infants before a first exchange transfusion; period II included samples taken after a first exchange transfusion, when only one was performed, or between a first and a second exchange transfusion, and so on.

\section{Results}

There were 166 cases with neonatal jaundice, 89 of which were given exchange transfusion one or more times (Table I). Definite signs of kernicterus were already present on admission in 9 infants. Of these, 3 died and the diagnosis of kernicterus was confirmed by post-mortem examination.

There were no preterm infants with definite signs of kernicterus. 2 preterm infants had convulsions and 4 had frequent attacks of apnoea. Of the latter, 2 died and in both intraventricular cerebral haemorrhage was found at post mortem, but there was no yellow staining of the basal ganglia.

Data from serum samples with more than 3 $\mathrm{mg} / 100 \mathrm{ml}$ conjugated bilirubin were excluded from the study, since from about this level the nontoxic conjugated bilirubin is adsorbed by the Sephadex column regardless of the total bilirubin concentration (unpublished observations).

In Fig. 1 and 2 the relation between the results of the Sephadex test and the serum bilirubin concentration and bilirubin/albumin molar ratio (B/A ratio), respectively, is presented. The number of specimens for which the ratio is available is smaller than that in which the bilirubin concentration was determined, since there was not enough serum for the estimation of albumin in all the specimens. From these figures it is obvious that the greater the bilirubin concentration or B/A ratio, the greater the proportion of positive Sephadex results. Among preterm infants there was a higher proportion of 
TABLE I

Analysis of clinical data

\begin{tabular}{|c|c|c|c|c|c|}
\hline $\begin{array}{l}\text { Aetiology of } \\
\text { jaundice }\end{array}$ & G6PD status * & No. of cases & $\begin{array}{l}\text { No. of cases } \\
\text { given exchange } \\
\text { transfusion }\end{array}$ & $\begin{array}{l}\text { Cases with } \\
\text { kernicterus }\end{array}$ & Remarks \\
\hline $\begin{array}{l}\text { Rhesus haemolytic } \\
\text { disease } \\
\text { ABO incompatibility }\end{array}$ & $\begin{array}{l}+ \\
+ \\
+\end{array}$ & $\begin{array}{r}6 \\
0 \\
22 \\
4\end{array}$ & $\begin{array}{r}6 \\
0 \\
13 \\
4\end{array}$ & $\begin{array}{l}3 \\
0 \\
0 \\
0\end{array}$ & $\begin{array}{l}\text { Group A or B infants of group O } \\
\text { mothers, with or without evidence of } \\
\text { haemolytic disease }\end{array}$ \\
\hline $\begin{array}{l}\text { No blood group } \\
\text { incompatibility }\end{array}$ & $\begin{array}{l}+ \\
-\end{array}$ & $\begin{array}{l}47 \\
13\end{array}$ & $\begin{array}{l}16 \\
10\end{array}$ & $\begin{array}{l}1 \\
2\end{array}$ & \\
\hline Prematurity & + & $\begin{array}{r}50 \\
2\end{array}$ & $\begin{array}{r}26 \\
1\end{array}$ & $\begin{array}{l}0 \\
0\end{array}$ & $\begin{array}{l}\text { Gestational age }<37 \mathrm{wk} \text {, birthweight } \\
<2.5 \mathrm{~kg}: 30 \text { cases } \\
\text { Gestational age }<37 \mathrm{wk} \text {, birthweight } \\
>2.5 \mathrm{~kg}: 6 \text { cases } \\
\text { Gestational age }>37 \mathrm{wk} \text {, birthweight } \\
<2.5 \mathrm{~kg}: 3 \text { cases } \\
\text { Gestational age unknown, birthweight } \\
<2.5 \mathrm{~kg}: 13 \text { cases }\end{array}$ \\
\hline $\begin{array}{l}\text { Insufficient } \\
\text { information }\end{array}$ & + & $\begin{array}{r}19 \\
3\end{array}$ & $\begin{array}{r}10 \\
3\end{array}$ & $\begin{array}{l}2 \\
1\end{array}$ & $\begin{array}{l}\text { All group A or B, direct Coombs's test } \\
\text { negative, mother's group unknown }\end{array}$ \\
\hline Total & + & $\begin{array}{r}144 \\
22\end{array}$ & $\begin{array}{l}71 \\
18\end{array}$ & $\begin{array}{l}6 \\
3\end{array}$ & \\
\hline
\end{tabular}

^G6PD status: + normal; - deficient.

positive Sephadex results at any given bilirubin concentration or $\mathrm{B} / \mathrm{A}$ ratio than among term infants. This difference was statistically significant at all bilirubin levels from $10 \cdot 1$ to $20 \mathrm{mg} / 100 \mathrm{ml}$ (Fig. 1), and at all $\mathrm{B} / \mathrm{A}$ ratios from 0.41 to 0.80 (Fig. 2).

Because most of the preterm infants were admitted before onset of jaundice, only a few reached high bilirubin levels before exchange transfusion and there were few ++ Sephadex results among them. However, many of the term infants already had very high bilirubin levels on admission, and the Sephadex test already gave ++ staining.

Unexpected findings included a negative Sephadex test in serum from a preterm infant with a bilirubin concentration of $33.7 \mathrm{mg} / 100 \mathrm{ml}$ and $B / A$ ratio of 0.94 (see Case 2), as well as in 2 samples from a term infant at bilirubin concentrations of $35 \cdot 7$ and $37.6 \mathrm{mg} / 100 \mathrm{ml}$ and $B / A$ ratios of $1 \cdot 11$ and $1 \cdot 17$. There were no signs of bilirubin encephalopathy in either case. On the other hand, + Sephadex results were obtained at low bilirubin levels (down to $4.9 \mathrm{mg} / 100 \mathrm{ml}$ ) in sera from preterm infants with severe respiratory distress, intracranial haemorrhage, or sepsis. In some of these cases the blood was drawn shortly before death.

The relation between age of the infant and the results of the Sephadex test was studied by separating the serum samples taken during period I into those taken from birth up to and including the 5 th day of life, and those taken from the 6th to the 12th day. Among sera taken from term infants 1 to
5 days after birth there was a higher proportion of positive Sephadex results than among sera taken from the infants when 6 days old or more, at most bilirubin levels (Fig. 3). This difference was statistically significant at all bilirubin levels from 17.6 to $25 \mathrm{mg} / 100 \mathrm{ml}$. On the other hand, among preterm infants there was no difference in the proportion of positive Sephadex results between sera taken before and those taken after the 6th day of life. However, among the preterm infants from whom serum was obtained on the 6th day of life and after were many very small and immature infants and infants with complications such as respiratory distress, apnoea, and sepsis, and those who were being treated with various drugs. Thus, in a preterm male (Case 1: birthweight $2350 \mathrm{~g}$, gestational age 36 weeks), who developed gastroenteritis on the 7th day of life and was started on gentamicin on the 10th day, the result of the Sephadex test was + as late as the 11 th day despite a bilirubin concentration of only $14 \mathrm{mg} / 100 \mathrm{ml}$. On the other hand, in another preterm male (Case 2: birthweight $2000 \mathrm{~g}$, gestational age 36 weeks), admitted in good condition on the 6th day of life, a negative Sephadex test was given by a serum sample with a bilirubin concentration of $33.7 \mathrm{mg} / 100 \mathrm{ml}$. $\mathrm{He}$ was transfused twice and the Sephadex test continued to be negative. Negative Sephadex tests were also given by two sera of a term infant with G6PD deficiency on the 12th day of life, at bilirubin levels of $35 \cdot 7$ and $37 \cdot 6 \mathrm{mg} / 100 \mathrm{ml}$. Furthermore, among the group of term infants only 2 out of 21 


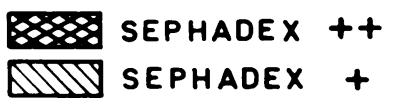

NUMBER OF SERA

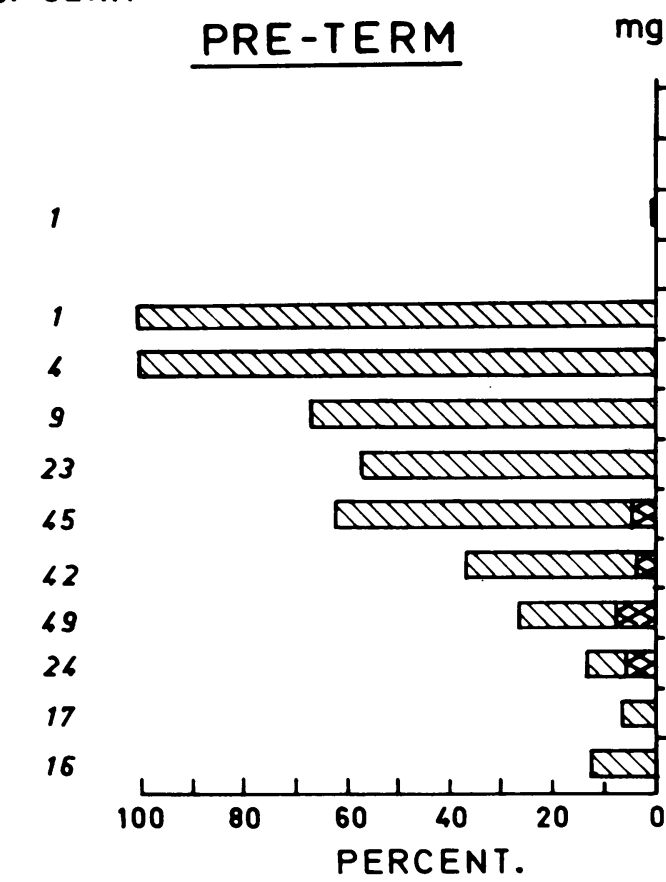

BILIRUBIN

NUMBER

OF SERA

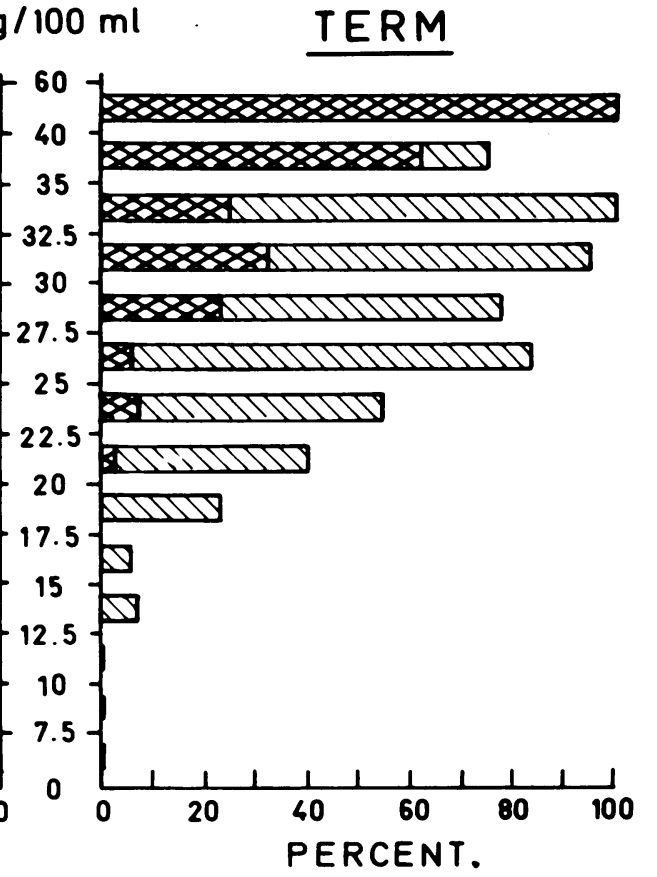

FIG. 1.-Sephadex test related to serum bilirubin concentration in preterm and term infants. Abscissa: percentage of total number of sera at each bilirubin level giving + or ++ Sephadex test. Note increase in proportion of positive Sephadex results with increase in bilirubin concentration. Differences $\left(\chi^{2}\right)$ between preterm and term infants: bilirubin 10-12.5 $\mathrm{mg} / 100 \mathrm{ml}, \mathrm{P}<0.05$; bilirubin $12 \cdot 5-15, P<0.005$; bilirubin 15-17.5, $P<0 \cdot 0005$; bilirubin $17 \cdot 5-20, P<0 \cdot 0005$.

++ Sephadex results were given by sera taken from infants aged 6 days or more.

The effect of in vivo haemolysis on the results of the Sephadex test could not be determined due to the small number of infants with overt haemolysis.

To determine whether the results of the Sephadex test were consistent during the course of jaundice in any given infant, the data were analysed as follows. For each infant each period was studied separately and only periods with 2 or more sera were included. The results were considered inconsistent if, despite an increase in bilirubin concentration of more than $2.5 \mathrm{mg} / 100 \mathrm{ml}$ (arbitrarily chosen range), a positive Sephadex test was followed by a negative test. The results were also considered inconsistent in the converse situation, when despite a decrease in bilirubin concentration of more than $2.5 \mathrm{mg} / 100 \mathrm{ml}$ a negative Sephadex test was followed by a positive test. In all other situations the results were considered consistent.

When the results of the Sephadex test performed without addition of bilirubin to the serum were analysed, the results were consistent in 70 out of 79 periods $(89 \%)$. In 48 of these 70 periods the consistency was absolute. In the other 22 periods the results were consistent when the margin of error in the difference in bilirubin concentrations between compared samples was within a range of $2.5 \mathrm{mg} / 100$ $\mathrm{ml}$. In only 9 periods $(11 \%)$ were the results inconsistent.

It was not possible to assess the ability of the use of bilirubin additions to serum to predict bilirubin binding affinity in cases with deepening jaundice because there were too few cases suitable for this type of analysis.

The relation between the results of the Sephadex 


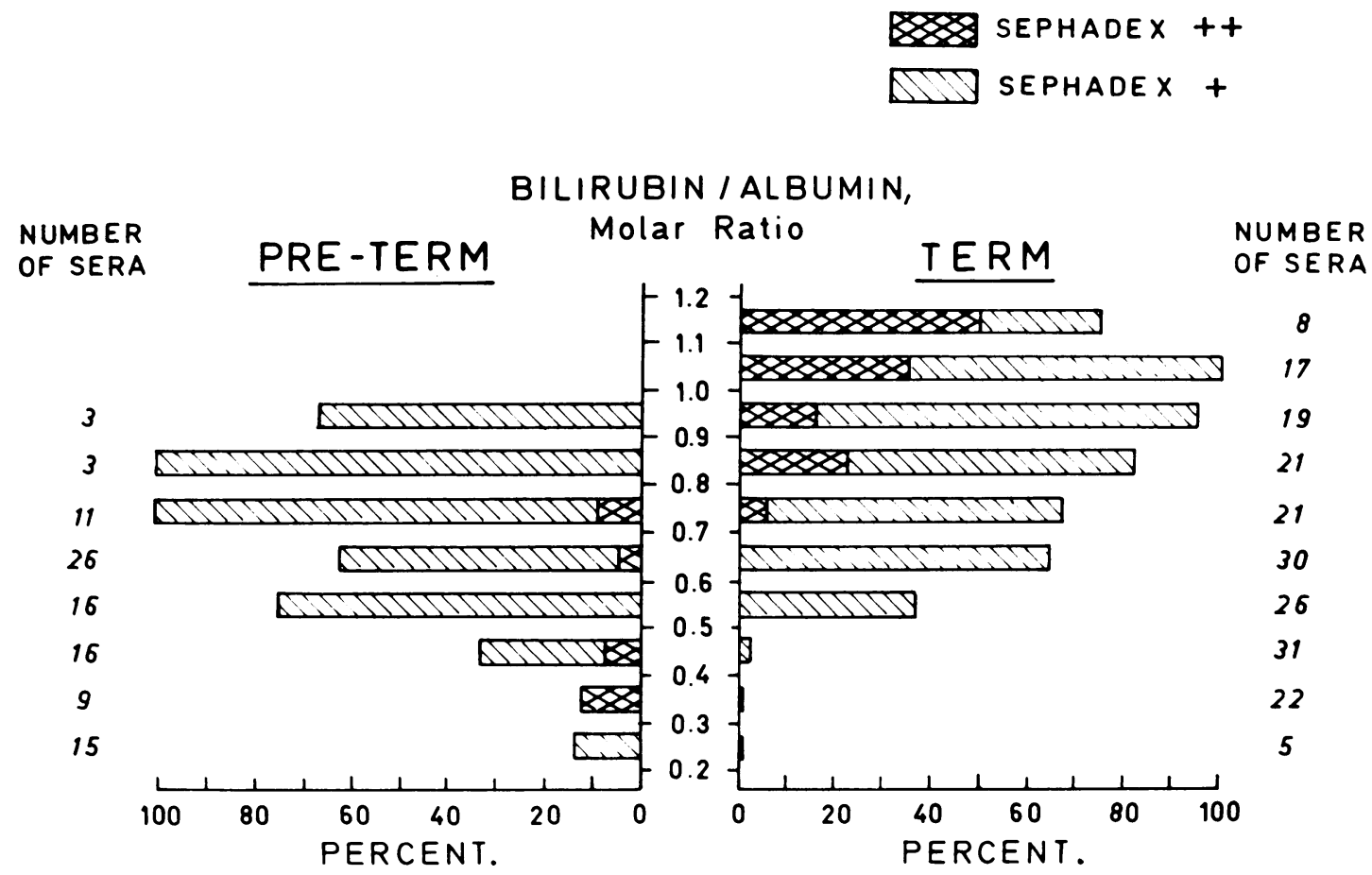

Fig. 2.-Sephadex test related to bilirubin/albumin molar ratio in preterm and term infants. Abscissa: percentage of total number of sera at each ratio giving + or ++ Sephadex test. Note increase in proportion of positive Sephadex results with increase in ratio. Differences $\left(\chi^{2}\right)$ between preterm and term infants: ratio $0 \cdot 4-0 \cdot 5, P<0 \cdot 01 ;$ ratio $0 \cdot 5-0 \cdot 6, P<0 \cdot 02$; ratio $0 \cdot 7-0 \cdot 8, P<0 \cdot 02$.

test and the actual management of the cases by the clinical staff (decision to exchange-transfuse based on bilirubin level and other clinical considerations) is shown in Table II. Before 73 of the 83 exchange transfusions that were performed in term infants $(88 \%)$ the Sephadex test was positive at least once, while before the other 10 transfusions $(12 \%)$ it was consistently negative. Conversely, in 61 of 96 periods not followed by exchange transfusion (64\%), the Sephadex test was consistently negative, but in the other 35 periods ( $36 \%$ ) the test was positive at least once. Thus, in 134 out of 179 periods ( $75 \%$ ) the independent decision whether or not to transfuse was compatible with the estimate of bilirubin binding as assessed by the Sephadex test. Had a positive Sephadex test been used as an indication for exchange transfusion, a total of 108 instead of 83 transfusions would have been performed. These relations held regardless of the aetiology of the jaundice.

In preterm infants, before 26 out of 37 exchange transfusions were performed $(70 \%)$ the Sephadex test was positive at least once, while in only 11 periods $(30 \%)$ was it consistently negative (Table II). Conversely, in 25 of 41 periods not followed by exchange transfusion $(61 \%)$ the Sephadex test was consistently negative, but in the other 16 periods $(39 \%)$ the test was positive at least once. Thus, in 51 out of 78 periods $(65 \%)$ the decision of the clinician was compatible with the information on binding supplied by the Sephadex test. Had a positive Sephadex test been used as an indication for exchange transfusion, a total of 42 instead of 37 transfusions would have been performed in the preterm infants.

The percentage of exchange transfusions performed despite a negative Sephadex test was significantly greater among preterm infants than among term infants $\left(\chi^{2}\right.$ test, $\left.P<0 \cdot 025\right)$. The decision to exchange-transfuse was most inconsistent with the results of the Sephadex test at bilirubin concentrations of between 20 and 25 $\mathrm{mg} / 100 \mathrm{ml}$ in term infants, and between 15 and 20 $\mathrm{mg} / 100 \mathrm{ml}$ in preterm infants (Table II), the bilirubin concentrations at which there is the greatest uncertainty as to the need for exchange 

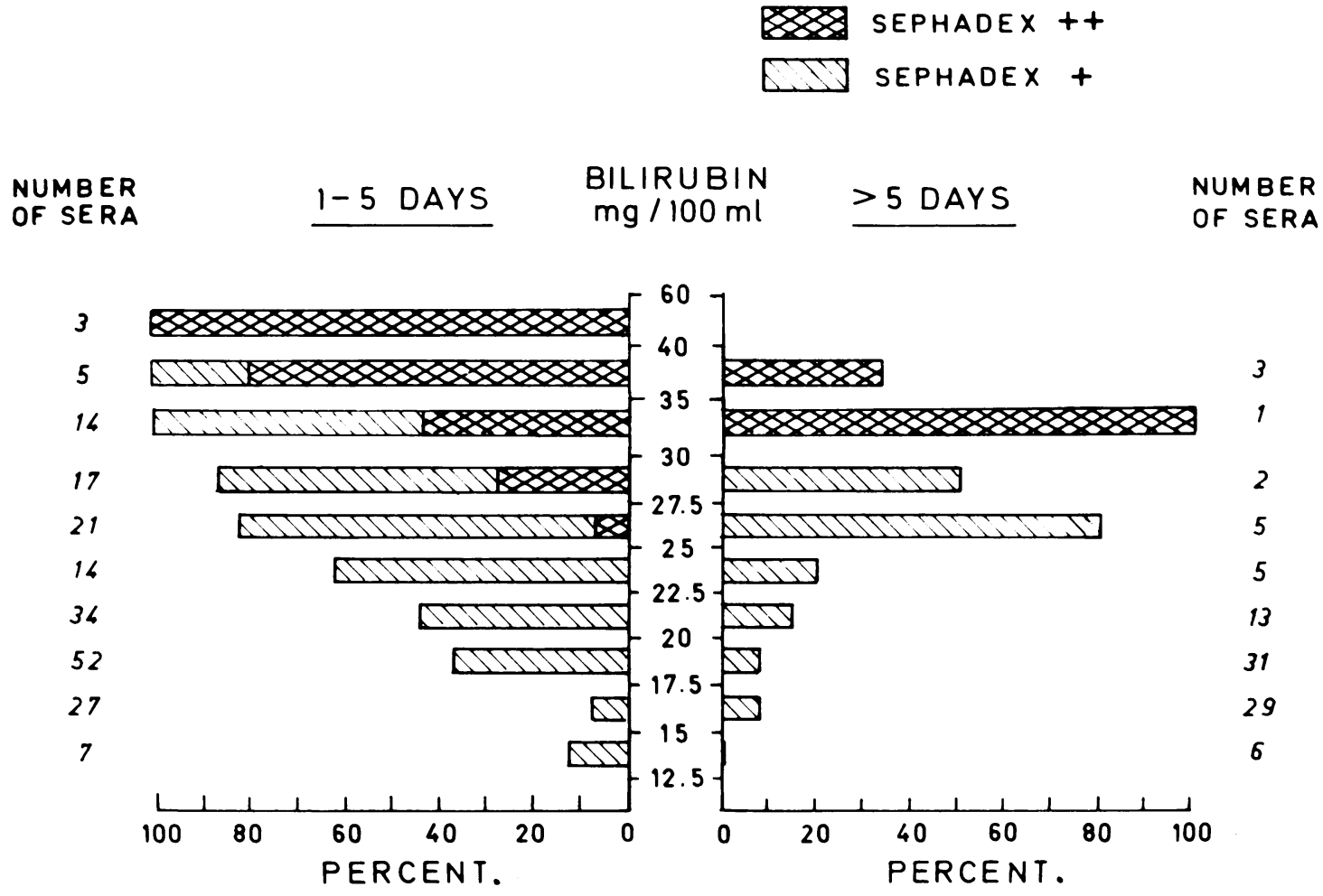

FIG. 3. - Sephadex test related to serum bilirubin concentration in term infants, before and after 6th day of life. Abscissa: percentage of total number of sera (obtained from infants not, or not yet, given exchange transfusion), at each bilirubin level, giving + or ++ Sephadex test. Note smaller proportion of sera giving positive Sephadex results on the 6th day of life and after, as compared with those obtained before: bilirubin 15-20 mg/100 ml, $P<0.005$; bilirubin 20-25, $P<0.02\left(\chi^{2}\right.$ test).

TABLE II

Relation between results of Sephadex test, serum bilirubin concentration, and use of exchange transfusion in infants with neonatal jaundice

\begin{tabular}{|c|c|c|c|c|c|c|c|c|c|c|c|c|c|c|c|c|}
\hline & \multirow{3}{*}{$\begin{array}{c}\text { Sephadex } \\
\text { test }\end{array}$} & \multirow{2}{*}{\multicolumn{3}{|c|}{ Exchange transfusion }} & \multicolumn{12}{|c|}{ Serum bilirubin concentration $(\mathrm{mg} / 100 \mathrm{ml})$} \\
\hline & & & & & \multicolumn{2}{|c|}{$\leqslant 10 \cdot 0$} & \multicolumn{2}{|c|}{$10 \cdot 1-15 \cdot 0$} & \multicolumn{2}{|c|}{$15 \cdot 1-20 \cdot 0$} & \multicolumn{2}{|c|}{$20 \cdot 1-25 \cdot 0$} & \multicolumn{2}{|c|}{$25 \cdot 1-30 \cdot 0$} & \multicolumn{2}{|c|}{$\geqslant 30 \cdot 1$} \\
\hline & & No & Yes & $\begin{array}{c}\% \\
\text { Exchanged }\end{array}$ & No & Yes & No & Yes & No & Yes & No & Yes & No & Yes & No & Yes \\
\hline All infants & $\begin{array}{c}\text { Negative } \\
+ \\
++\end{array}$ & $\begin{array}{c}86 \\
49 \\
2^{\star}\end{array}$ & $\begin{array}{l}21 \\
76 \\
23\end{array}$ & $\begin{array}{l}20 \\
61 \\
92\end{array}$ & $\frac{2}{-}$ & - & $\begin{array}{r}4 \\
5 \\
-\end{array}$ & $\frac{-}{1}$ & $\begin{array}{r}44 \\
8 \\
1\end{array}$ & $\begin{array}{l}3 \\
6 \\
2\end{array}$ & $\begin{array}{l}33 \\
33 \\
\end{array}$ & $\begin{array}{r}7 \\
18 \\
-\end{array}$ & $\begin{array}{l}3 \\
3 \\
1\end{array}$ & $\begin{array}{r}8 \\
33 \\
2\end{array}$ & - & $\begin{array}{r}3 \\
18 \\
19\end{array}$ \\
\hline Preterm & $\begin{array}{c}\text { Negative } \\
+ \\
++\end{array}$ & $\begin{array}{l}25 \\
15 \\
1 \star\end{array}$ & $\begin{array}{r}11 \\
24 \\
2\end{array}$ & $\begin{array}{l}31 \\
62\end{array}$ & $\frac{2}{-}$ & - & $\begin{array}{r}3 \\
4 \\
-\end{array}$ & - & $\begin{array}{r}16 \\
6 \\
1\end{array}$ & $\begin{array}{l}3 \\
6 \\
2\end{array}$ & $\begin{array}{r}4 \\
5 \\
-\end{array}$ & $\begin{array}{r}4 \\
12 \\
-\end{array}$ & - & $\begin{array}{r}3 \\
4 \\
-\end{array}$ & - & $\begin{array}{l}1 \\
1 \\
\end{array}$ \\
\hline Term & $\begin{array}{c}\text { Negative } \\
+ \\
++\end{array}$ & $\begin{array}{r}61 \\
34 \\
1\end{array}$ & $\begin{array}{l}10 \\
52 \\
21\end{array}$ & $\begin{array}{l}14 \\
60 \\
95\end{array}$ & - & - & $\begin{array}{r}1 \\
1 \\
-\end{array}$ & - & $\begin{array}{r}28 \\
2 \\
-\end{array}$ & - & $\begin{array}{l}29 \\
28 \\
-\end{array}$ & $\begin{array}{r}3 \\
6 \\
-\end{array}$ & $\begin{array}{l}3 \\
3 \\
1\end{array}$ & $\begin{array}{r}5 \\
29 \\
2\end{array}$ & - & $\begin{array}{r}2 \\
17 \\
19\end{array}$ \\
\hline
\end{tabular}

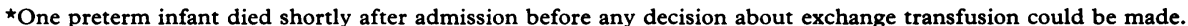

Note: The number of positive or negative decisions to give exchange transfusion (one decision per 'period' per infant) is indicated. This decision is related in the Table to the maximum Sephadex result, and to the highest serum bilirubin concentration at which this result was obtained in each 'period' in each infant (see methods for definition of 'period'). 
transfusion. On the other hand, there were also inconsistencies at both lower and higher bilirubin concentrations, especially among preterm infants.

The Sephadex test was strongly positive $(++)$ in one or more specimens from 22 cases: 3 cases with rhesus haemolytic disease, 2 with $\mathrm{ABO}$ incompatibility, 3 without blood group incompatibility, 8 with G6PD deficiency, 2 with prematurity, and 4 with insufficient information. Among them were all the 9 cases with clinically diagnosed kernicterus. In 6 of the 22 cases, including 3 cases with kernicterus, high conjugated bilirubin levels were found in serum. All except 2 of the cases with ++ Sephadex results were transfused. One of the 2 not transfused was a preterm infant who died shortly after admission, before a decision about transfusion was made.

\section{Discussion}

Sephadex gel filtration of serum from jaundiced newborns was used in this study to evaluate the equilibrium between the bilirubin-albumin complex and the unbound (free) fraction of bilirubin in serum. Unbound bilirubin, found only in very low concentrations in serum (Jacobsen and Fedders, 1970), is adsorbed by Sephadex during filtration (Kaufmann et al., 1969), and as a result more bilirubin dissociates from its complex with albumin in order to restore the equilibrium. Therefore, only a fraction of the total amount of bilirubin adsorbed by the Sephadex column had been in the free state in the native serum, while the rest was liberated during passage of the serum through the column.

The dissociation of bilirubin depends on the strength of its bond to albumin. It is generally agreed that one molecule of human serum albumin binds 2 molecules of bilirubin. There are two classes of binding sites on the albumin molecule, each of which binds bilirubin with a different dissociation constant (Odell, 1959; Kaufmann, Simcha, and Blondheim, 1967; Bjerrum, 1968). Bilirubin is bound less tightly to the second class of binding sites than to those of the first class. Therefore, relatively more bilirubin will dissociate from the albumin once the binding sites of the first class are saturated. Another factor which may affect the release of bilirubin from albumin is the affinity of Sephadex itself for bilirubin. Thus Sephadex gel filtration of jaundiced serum may constitute a model reflecting the partition of bilirubin between serum and the brain tissue, assuming that the affinities for bilirubin of Sephadex gel and brain tissue are of a similar order of magnitude.

The Sephadex technique used in this study has many advantages for clinical use. The volume of serum used is only $0.1 \mathrm{ml}$, no special reagents or instruments are needed, and the test can be easily and rapidly performed, even at the bedside. Other Sephadex techniques include elution and quantitation of the bilirubin adsorbed on the column (Kaufmann et al., 1969; Zamet and Chunga, 1971; Schiff et al., 1972), while with the technique we use, the adsorbed bilirubin reacts with a diazo reagent on the column itself. This qualitative technique correlates well with a quantitative method, and may actually give more reliable information about the binding of bilirubin at low concentrations than the quantitative test (Kaufmann, Kapitulnik, and Blondheim, 1973).

The results of the present study with fresh sera confirm those previously reported for a smaller series of frozen sera (Blondheim et al., 1972). Kernicterus was diagnosed in almost half the present cases which gave a ++ Sephadex test at least once (9 out of 22 cases). In cases which gave only a + or a negative Sephadex test, kernicterus was not found. Follow-up is required in order to determine whether or not evidence of brain damage might appear in cases in which bilirubin encephalopathy was not diagnosed in hospital.

Since the aim of exchange transfusion is to prevent even minimal brain damage, not only infants at high risk but also those in lesser degrees of danger should be transfused. A ++ Sephadex result identifies infants in whom the limit of safety has already been passed, as evidenced by the high incidence of kernicterus in cases with the ++ reaction, and exchange transfusion should be performed at once in such cases. Exchange transfusion should also be considered whenever a + result is obtained, since this result indicates that bilirubin is bound to the second class of binding sites which have a lower affinity for bilirubin than those of the first class (Kaufmann et al., 1973). Thus, in cases with a + reaction, bilirubin is probably readily liberated from the circulating serum albumin and could cause bilirubin encephalopathy. On the other hand, a negative Sephadex test appears to define fairly well the population of jaundiced infants not in immediate danger of bilirubin encephalopathy, as infants in our series who consistently gave a negative Sephadex test never showed evidence of bilirubin encephalopathy, even when bilirubin concentrations were above $30 \mathrm{mg} / 100 \mathrm{ml}$. A similar conclusion was reached by those using other Sephadex techniques when the gel did not adsorb bilirubin (Zamet and Chunga, 1971; Schiff et al., 1972).

Had a + Sephadex result been used in our 
material as the only criterion for exchange transfusion, instead of the bilirubin level in the light of the general clinical picture, a few more transfusions would have been performed. Some infants who were not exchanged would have been, and vice versa as well. This is of special importance at those bilirubin concentrations at which there is the most uncertainty about management, as in term infants with bilirubin levels between 20 and $25 \mathrm{mg} / 100 \mathrm{ml}$ and preterm infants with levels between 15 and 20 $\mathrm{mg} / 100 \mathrm{ml}$. Of particular importance are the preterm infants, for whom the performance of exchange: transfusion bears a special risk. Again, careful follow-up for late evidence of brain damage is needed to determine whether the use of the Sephadex test as a major criterion for exchange transfusion will further reduce the incidence of brain damage by improving the selection of cases for exchange transfusion.

Additional information can be obtained by artificially increasing the bilirubin concentration in sera giving a negative Sephadex test. In this way the bilirubin concentration at which these sera would probably give a + Sephadex result is determined. The information thus obtained might be useful as a guideline in the further management of the case. However, the clinical condition of the infant is dynamic and there are many factors which affect the binding of bilirubin to albumin, particularly in preterm infants in whom acidosis, anoxia, and sepsis are common. Furthermore, some antibiotics used in neonatal sepsis affect the binding of bilirubin to albumin (Odell, 1959; Kapitulnik, Eyal, and Simcha, 1972b; Stern, 1972; Kapitulnik et al., 1974a), and their use may therefore decrease the predictive value of the Sephadex test. Thus, the ability of serum to bind more bilirubin at a given moment might not reflect the ability of serum taken some time later. Because of these limitations it is suggested that the Sephadex test be repeated a few times a day, rather than to rely solely on the results of a single test.

Apart from the clinical evaluation of the Sephadex test, this study provides new information on the relation between the binding of bilirubin to albumin and the degree of maturity and the age of the infant. Thus, decreased binding was found in preterm infants as compared with term infants, even after allowing for the lower albumin concentration of preterm infants by comparing $\mathrm{B} / \mathrm{A}$ ratios. This suggests that other factors as well are responsible for the decreased binding of bilirubin by preterm infants, such as a possible structural difference in the albumin molecule and/or the presence of substances in serum which interfere with bilirubin binding.
These findings provide a fuller explanation for the occurrence of kernicterus at very low serum bilirubin levels in low birthweight preterm infants with severe complications (Hsia et al., 1952; Stern and Denton, 1965; Ackerman, Dyer, and Leydorf, 1970; Gartner et al., 1970). Thus, in our material there were a few preterm infants who were severely ill with complications such as apnoea, respiratory distress syndrome, or sepsis, who gave a ++ Sephadex result at bilirubin concentrations as low as $11.5 \mathrm{mg} / 100 \mathrm{ml}$ (B/A ratio $0 \cdot 38$ ).

Among term infants increased binding affinity for bilirubin was found in serum obtained on and after the 6th day of life, as compared with serum taken during the first 5 days of life, despite the known decrease in albumin concentrations during the neonatal period. In an earlier report decreased binding affinity for bilirubin has been found in cord blood serum as compared with adult serum (Kapitulnik, Blondheim, and Kaufmann, 1972a). The present findings indicate that the transition from the newborn to the adult pattern of bilirubin binding starts during the first week of life and continues until about the fifth month, when the adult pattern is approximated (Kapitulnik et al., 1974b). However, this does not prevent bilirubin encephalopathy from developing after the first week of life in cases in which there is a very marked late increase in serum bilirubin levels such as occurs in G6PD deficiency (Doxiadis and Valaes, 1964).

Among preterm infants no changes in bilirubin binding were found in relation to age, but most samples obtained on the 6th day and thereafter were from very immature or very sick infants. It is possible that high concentrations of substances interfering with the binding of bilirubin were still present in the serum of these preterm infants after the first week of life, at which time their concentration in the serum of term infants had apparently considerably decreased.

Conjugated, as opposed to unconjugated, bilirubin does not cause bilirubin encephalopathy, and only rarely is it significantly increased during the neonatal period. However, since it is adsorbed by Sephadex from serum at very low total bilirubin concentrations, it may produce a misleading positive Sephadex result (A. Priolisi, personal communication, 1973). Therefore, the concentration of conjugated bilirubin should be determined in cases whose sera give positive Sephadex results in order to evaluate correctly the clinical status of the infant.

It was not possible under the circumstances of the present study to compare the results of the Sephadex technique with those of other methods suggested for the estimation of bilirubin binding (Porter and 
Waters, 1966; Odell, Cohen, and Kelly, 1969; Jacobsen and Fedders, 1970; Bratlid, 1972). However, the Sephadex test does appear to estimate the overall effect of the many factors affecting bilirubin binding by albumin in serum. Prolonged follow-up of the cases studied with this technique is needed to prove whether it can be relied on as a major criterion in the prevention of bilirubin encephalopathy.

We thank Professor S. Doxiadis, Director of the Paediatric Unit, and Professor N. Matsaniotis, Director of the University Paediatric Clinic of the Aghia Sophia Children's Hospital, and their associates for cooperation in providing clinical material, and Miss A. Zografu for her skilful technical assistance. This study was supported by the Israel Foreign Ministry and the Ames-Yissum Co. of Jerusalem.

\section{REFERENCES}

Ackerman, B. D., Dyer, G. Y., and Leydorf, M. M. (1970). Hyperbilirubinemia and kernicterus in small premature infants. Pediatrics, 45, 918.

Bierrum, O. J. (1968). Interaction of bromphenol blue and bilirubin with bovine and human serum albumin determined by gel filtration. Scandinavian fournal of Clinical and Laboratory Investigation, $22,41$.

Blondheim, S. H., Kapitulnik, J., Valaes, T., and Kaufmann, N. A. (1972). Use of a Sephadex column to evaluate the bilirubinbinding capacity of the serum of infants with neonatal jaundice. Israel fournal of Medical Sciences, 8, 22.

Bratlid, D. (1972). Bilirubin binding by human erythrocytes. Scandinavian fournal of Clinical and Laboratory Investigation, 29, 91

Doxiadis, S. A., and Valaes, T. (1964). The clinical picture of glucose-6-phosphate dehydrogenase deficiency in early infancy. Archives of Disease in Childhood, 39, 545.

Fernandez, A., Sobel, C., and Goldenberg, H. (1966). An improved method for determination of serum albumin and globulin. Clinical Chemistry, 12, 194.

Gartner, L. M., Snyder, R. N., Chabon, R. S., and Bernstein, J. (1970). Kernicterus: high incidence in premature infants with low serum bilirubin concentrations. Pediatrics, 45, 906.

Hsia, D. Y., Allen, F. H., Gellis, S. S., and Diamond, L. K. (1952). Erythroblastosis fetalis. VII. Studies of serum bilirubin in relation to kernicterus. New England fournal of Medicine, 247, 668.

Jacobsen, J., and Fedders, O. (1970). Determination of nonalbumin-bound bilirubin in human serum. Scandinavian fournal of Clinical and Laboratory Investigation, 26, 237.

Jirsová, V., Jirsa, M., Heringová, A., Koldovsky, O., and Weirichová, J. (1967). The use and possible diagnostic significance of
Sephadex gel filtration of serum from icteric newborn. Biologia Neonatorum, 11, 204.

Kapitulnik, J., Blondheim, S. H., and Kaufmann, N. A. (1972a). Sephadex adsorption of bilirubin from neonatal and adult serum. Clinical Chemistry, 18, 43.

Kapitulnik, J., Eyal, F., and Simcha, A. J. (1972b). Gentamicin and bilirubin-binding by plasma. Lancet, 2, 1195.

Kapitulnik, J., Eyal, F., Simcha, A. J., and Blondheim, S. H. (1974a). Effect of drugs on binding of bilirubin to serum albumin in jaundiced neonates: use of sephadex gel filtration to detect possible toxicity. Proceedings of the International Symposium on Hepatotoxicity. Academic Press, New York.

Kapitulnik, J., Horner-Mibashan, R., Blondheim, S. H., Kaufmann, N. A., and Russell, A. (1974b). Increase in bilirubin binding affinity of infant serum with age. fournal of Pediatrics. (In the press.)

Kaufmann, N. A., Kapitulnik, J., and Blondheim, S. H. (1969). The adsorption of bilirubin by Sephadex and its relationship to the criteria for exchange transfusion. Pediatrics, 44, 543.

Kaufmann, N. A., Kapitulnik, J., and Blondheim, S. H. (1973). Bilirubin binding affinity of serum: comparison of qualitative and quantitative Sephadex gel filtration methods. Clinical Chemistry, 19, 1276.

Kaufmann, N. A., Simcha, A. J., and Blondheim, S. H. (1967). The uptake of bilirubin by blood cells from plasma and its relationship to the criteria for exchange transfusion. Clinical Science, 33, 201.

Lathe, G. H., and Ruthven, C. R. J. (1958). Factors affecting the rate of coupling of bilirubin and conjugated bilirubin in the van den Bergh reaction. Fournal of Clinical Pathology, 11, 155.

Malloy, H. T., and Evelyn, K. A. (1937). The determination of bilirubin with the photoelectric colorimeter. Fournal of Biological Chemistry, 119, 481.

Odell, G. B. (1959). The dissociation of bilirubin from albumin and its clinical implications. Fournal of Pediatrics, 55, 268.

Odell, G. B., Cohen, S. N., and Kelly, P. C. (1969). Studies in kernicterus. II. The determination of the saturation of serum albumin with bilirubin. Fournal of Pediatrics, 74, 214.

Porter, E. G., and Waters, W. J. (1966). A rapid micromethod for measuring the reserve albumin binding capacity in serum from newborn infants with hyperbilirubinemia. Fournal of Laboratory and Clinical Medicine, 67, 660.

Schiff, D., Chan, G., and Stern, L. (1972). Sephadex G-25 quantitative estimation of free bilirubin potential in jaundiced newborn infants' sera: a guide to the prevention of kernicterus. Fournal of Laboratory and Clinical Medicine, 80, 455.

Stern, L. (1972). Drug interactions. II. Drugs, the newborn infant, and the binding of bilirubin to albumin. Pediatrics, 49, 916.

Stern, L., and Denton, R. L. (1965). Kernicterus in small premature infants. Pediatrics, 35, 483.

Zamet, $P$, and Chunga, F. (1971). Separation by gel filtration and microdetermination of unbound bilirubin. II. Study of sera in icteric newborn infants. Acta Paediatrica Scandinavica, 60, 33.

Correspondence to Dr. S. H. Blondheim, Hadassah Hospital, Jerusalem, Israel. 